\title{
Pengembangan Media Spasi \\ (Sistem Pencernaan Sapi) Pada Materi IPA Siswa Kelas V SDN Bendan Ngisor Semarang
}

\author{
Heru Kristianto ${ }^{1}$ \\ 1) Program Studi PGSD Universitas PGRI Semarang; HeruCiez36@Gmail.com
}

\begin{abstract}
Abstrak. Penelitian ini diawali dari sebagian besar siswa yang kesulitan dalam memahami materi pencernaan makanan pada hewan ruminansia mata pelajaran IPA. Permasalahan tersebut menjadi pertimbangan bagi peneliti untuk melakukan penelitian. Penelitian ini bertujuan untuk menghasilkan media pembelajaran SPASI (Sistem Pencernaan Sapi) dan mengetahui kualitas media pembelajaran SPASI (Sistem Pencernaan Sapi). Penelitian ini dilakukan kepada sekelompok siswa kelas V di SD Bendan Ngisor Semarang. Jenis penelitian ini adalah penelitian dan pengembangan yang diadaptasi dari tahapan Sugiyono serta Borg and Gall yang kemudian dimodifikasai antara lain potensi dan masalah, pengumpulan data, desain produk, validasi, uji coba pemakaian, revisi produk, uji coba produk, revisi desain, revisi produk. Hasil dari penelitian ini adalah prototipe pembelajaran IPA mengenai sistem pencernaan makanan pada hewan ruminansia. Media pembelajaran SPASI (Sitem Pencernaan Sapi) memiliki kualitas sangat baik dilihat dari hasil validasi yang dilakukan oleh ahli IPA dan Montessori. Perolehan skor rerata sebesar 3,85. Uji coba terbatas menunjukikan terdapat peningkatan nilai yang diperoleh siswa. Selisih nilai posttest dengan pretest sebesar 40. Dengan demikian, dapat disimpulkan bahwa media pembelajaran SPASI (Sistem Pencernaan Sapi) memiliki kualitas yang sangat baik dan membantu siswa memahami materi pencernaan makanan pada hewan ruminansia.
\end{abstract}

Kata Kunci: Pencernaan Makanan, Media Pembelajaran, SPASI.

Abstract. This research was initiated from the majority of students who had difficulty understanding food digestion material in ruminants in natural science subjects. These problems are considered by researchers to conduct research. This study aims to produce SPASI learning media (Cow Digestive System) and determine the quality of SPASI learning media. This research was conducted to a group of fifth grade students at Bendan Ngisor Elementary School in Semarang. This type of research is research and development adapted from the Sugiyono and Borg $\mathcal{E}$ Gall stages which are then modified including potential and problems, data collection, product design, validation, trial use, product revision, product trial, product revision, product revision. The results of this study are a prototype of learning

Caruban: Jurnal Ilmiah Pendidikan Dasar 3(1), 15-28, Januari 2020

DOI: http://dx.doi.org/10.33603/.v3i1.3037, p-ISSN 2615-1391, e-ISSN 2620-3219

CProdi PGSD Universitas Swadaya Gunung Jati 
science about the digestive system of food in ruminant animals. The learning media of SPASI has a very good quality seen from the results of the validation done by science experts and Montessori. Average score of 3.85. Limited trials show there is an increase in students' grades. The difference between the posttest score with a pretest of 40 . Thus, it can be concluded that the learning media SPASI has very good quality and helps students understand food digestion material in ruminant animals.

Keywords: Food Digestion, Learning Media, SPASI

\section{Pendahuluan}

Ilmu Pengetahuan Alam (IPA) merupakan salah satu mata pelajaran di SD yang dimaksudkan agar peserta didik mempunyai pengetahuan, gagasan dan konsep yang terorganisasi tentang alam sekitar, yang diperoleh dari pengalaman melalui serangkaian proses ilmiah antara lain penyelidikan, penyusunan dan penyajian gagasan-gagasan baru. IPA adalah pengetahuan khusus yaitu dengan melakukan observasi, eksperimentasi, penyimpulan, penyusunan teori dan demikian seterusnya kait mengait antara cara yang satu dengan cara yang lain. IPA berhubungan dengan cara mencari tahu tentang alam secara sistematis, sehingga IPA bukan hanya penguasaan kumpulan sistematis dan IPA bukan hanya penguasaan kumpulan pengetahuan yang berupa fakta-fakta, konsep-konsep atau prinsip-prinsip saja, tetapi juga merupakan suatu proses penemuan (Sulistroyini dalam Rullyanda, 2014). IPA adalah ilmu yang mempelajari peristiwa-peristiwa yang terjadi di alam (Iskandar dalam Rullyanda, 2014). Ilmu Pengetahuan Alam merupakan mata pelajaran di Sekolah Dasar yang dimaksudkan agar siswa mempunyai pengetahuan, gagasan dan konsep yang terorganisasi tentang alam sekitar, yang diperoleh dari pengalaman melalui serangkaian proses ilmiah antara lain penyelidikan, penyusunan dan penyajian gagasangagasan. Pada prinsipnya mempelajari IPA sebagai cara mencari tahu dan cara mengerjakan atau melakukan dan membantu siswa untuk memahami alam sekitar secara lebih mendalam (Depdiknas dalam Rullyanda, 2014).

Dalam menyiapkan pembelajaran, guru dituntut juga untuk dapat menarik perhatian siswa, mempersiapkan penyampaian informasi atau materi pembelajaran yang mudah serta media pembelajaran yang dapat digunakan untuk menyampaikan informasi atau materi pelajaran tersebut. Hal ini sesuai dengan pendapat Kustandi dan Sutjipto (2011: 9), bahwa media

Caruban: Jurnal Ilmiah Pendidikan Dasar 3(1), 15-28, Januari 2020

DOI: http://dx.doi.org/10.33603/.v3i1.3037, p-ISSN 2615-1391, e-ISSN 2620-3219

(CProdi PGSD Universitas Swadaya Gunung Jati 
pembelajaran adalah alat yang dapat membantu proses belajar mengajar dan berfungsi untuk memperjelas makna pesan yang disampaikan, sehingga dapat mencapai tujuan pembelajaran dengan lebih baik dan sempurna. Penggunaan media sangat diperlukan untuk memudahkan penyerapan materi bagi siswa SD sesuai standar kompetensi kelulusan yang merupakan kualifikasi kemampuan kelulusan yang mencakup sikap, pengetahuan, dan keterampilan sebagaimana yang telah ditetapkan dalam standar proses kurikulum 2013. Media pembelajaran menjadi bagian penting yang harus mendapat perhatian dari guru. Media pembelajaran digunakan untuk menyampaikan informasi atau materi pelajaran. Menurut Sadiman (1993) dalam Kustandi dan Sutjipto (2011: 7), media adalah perantara atau pengantar pesan dari pengirim ke penerima pesan. Selain menggunakan media, pendidik juga harus mengetahui bagaimana cara mengelola pembelajaran yang berlangsung pada setiap proses pembelajaran. Salah satu cara agar guru dapat melakukan proses pembelajaran dengan baik adalah mengetahui karakteristik materi dari mata pelajaran yang akan diajarkan kepadanya.

Berdasarkan hasil wawancara dan informasi dari guru kelas V SD Negeri Bendan Ngisor Semarang, yaitu pada saat proses pembelajaran kendala yang dihadapi siswa adalah pada saat pembelajaran siswa kurang berkonsentrasi dan kurang tertarik dalam menerima materi pembelajaran yang dijelaskan guru apabila materi tersebut banyak berisi tentang penjelasan. Hal itu dikarenakan pada proses pembelajaran media pembelajaran yang digunakan kurang mendukung pembelajaran karena guru hanya menggunakan media gambar diam sehingga siswa kurang paham dan mengerti. Selain itu diperoleh data bahwa, sikap siswa kelas $\mathrm{V}$ dalam proses pembelajaran kurang disiplin terbukti ketika proses pembelajaran sedang berlangsung terdapat beberapa siswa yang masih sibuk dengan kegiatanya sendiri. Siswa tidak memerhatikan penjelasan guru. Semangat siswa dalam proses pembelajaran juga kurang, hal ini terbukti dari banyaknya siswa yang bersikap tak acuh dalam proses pembelajaran. Salah satu strategi yang dapat digunakan adalah dengan menggunakan media pembelajaran yang mendukung materi pembelajaran dengan kesesuaian karakteristik siswa. Penggunaan media pembelajaran dalam proses pembelajaran diharapkan dapat memacu siswa untuk lebih aktif dalam pembelajaran dan hasil belajar

Caruban: Jurnal Ilmiah Pendidikan Dasar 3(1), 15-28, Januari 2020

DOI: http://dx.doi.org/10.33603/.v3i1.3037, p-ISSN 2615-1391, e-ISSN 2620-3219

CProdi PGSD Universitas Swadaya Gunung Jati 
siswa menjadi lebih aktif. Pada usia Sekolah Dasar yaitu usia antara 6-12 tahun biasanya siswa lebih banyak mengetahui pada hal-hal baru yang dialaminya serta mampu menarik perhatiannya. Pada usia tersebut siswa akan dilatih untuk berpikir secara kristis dan objektif atau terdapat objeknya serta lebih ke arah rasional atau masuk akal dalam mengambil sebuah keputusan, karena siswa merasakan secara sendirinya dalam melakukan pengamatan atau pengalaman dalam proses pembelajaran. Dengan kata lain dapat dikatakan bahwa pada usia yang demikian, siswa akan termotivasi dalam proses pembelajaran dimana hal itu didapatkan dari peran guru yang menampilkan proses pembelajaran yang inovatif dan efektif dengan bantuan media pembelajaran.

Berdasarkan permasalahan yang ada, maka perlu adanya penelitian berkaitan dengan media pembelajaran yang sesuai dengan karakteristik siswa untuk meningkatkan minat belajar siswa pada mata pelajaran IPA materi sistem pencernaan hewan ruminansia dan perlu adanya media pembelajaran yang dapat menumbuhkan minat siswa agar antusias dalam menjalani proses pembelajaran. Salah satu cara untuk meningkatkan minat dan prestasi belajar siswa adalah menggunakan media pembelajaran dan siswa akan terlibat secara langsung dalam proses pembelajaran dengan adanya media pembelajaran. Media pembelajaran SPASI (Sistem Pencernaan Sapi) adalah media pembelajaran yang berbentuk replika tubuh sapi dengan menekankan pada organ-organ pencernaannya, dengan urutan pencernaan yang pertama melalui mulut sapi yang terdiri dari (gigi, lidah dan saliva) setelah proses awal pencernaan selanjutnya melalui lambung sapi yang terdiri dari 4 bagian, yaitu (rumen atau perut besar, retikulum atau perut jala, omasum atau perut kitab dan obamasum atau perut masam) setelah melewati proses pencernaan melalui lambung sapi selanjutnya makanan akan bergerak menuju usus halus dan pada bagian tersebut makanan akan terjadi proses absorpsi dan fermentasi yang selanjutnya sisa makanan akan dikeluarkan melalui anus. Pada media pembelajaran SPASI (Sistem Pencernaan Sapi) akan lebih menekankan pada tahap demonstrasi sistem pencernaan dan melibatkan siswa dalam proses tersebut agar siswa dapat mengetahui dan paham dengan materi sistem pencernaan hewan ruminansia sapi. Berdasarkan uraian latar belakang yang telah dijabarkan, maka penulis perlu melakukan pengembangan produk media pembelajaran

Caruban: Jurnal Ilmiah Pendidikan Dasar 3(1), 15-28, Januari 2020

DOI: http://dx.doi.org/10.33603/.v3i1.3037, p-ISSN 2615-1391, e-ISSN 2620-3219

CProdi PGSD Universitas Swadaya Gunung Jati 
dengan judul "Pengembangan Media SPASI (Sistem Pencernaan Sapi) Pada Materi IPA Siswa Kelas V SDN Bendan Ngisor Semarang."

\section{Metode}

Penelitian ini termasuk jenis Penelitian dan Pengembangan (Reseach and Development) yang merupakan metode penelitian secara sengaja, sistematis, bertujuan/diarahkan untuk mencaritemukan, merumuskan, memperbaiki, mengembangkan, menghasilkan, menguji keefektifan produk, model, metode/strategi/cara, jasa, prosedur tertentu yang lebih unggul, baru, efektif, efisien, produktif, dan bermakna. (Putra, 2015: 67). Penelitian dan pengembangan (Reseach and Development) ini dilakukan dalam proses untuk menghasilkan sebuah produk baru. Model penelitian dan Pengembangan ini mengacu pada tahapan Reseach and Deveopment (R\&D) yang dikemukakan oleh Borg and Gall yang terdapat dalam Sugiyono (2010:409), langkahlangkah tersebut yaitu 1) potensi dan masalah, 2) pengumpulan data, 3) desain produk, 4) validasi, 5) uji coba pemakaian, 6) revisi produk, 7) uji coba produk, 8) revisi desain, 9) revisi produk, 10) produksi masal.

Prosedur pengembangan media SPASI disesuaikan dengan langkah tersebut, namun dibatasi hingga pada tahap revisi produk tahap akhir karena penelitian ini hanya sampai menguji kelayakan produk bukan untuk produksi masal. Tahapan tersebut dapat dilihat pada Gambar 1.

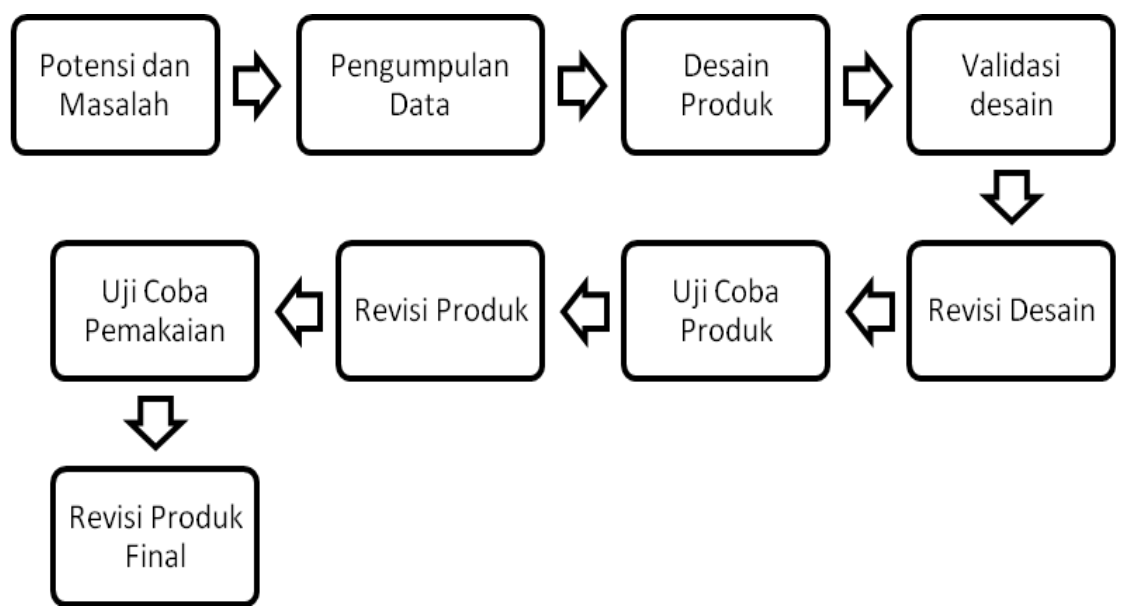

Gambar 1. Tahapan Pengembangan Menurut Borg \& Gall

Penelitian ini berangkat dari adanya suatu potensi atau masalah. Potensi adalah sesuatu yang bila didayagunakan memiliki nilai tambah yang lebih.

Caruban: Jurnal Ilmiah Pendidikan Dasar 3(1), 15-28, Januari 2020

DOI: http://dx.doi.org/10.33603/.v3i1.3037, p-ISSN 2615-1391, e-ISSN 2620-3219

CProdi PGSD Universitas Swadaya Gunung Jati 
Sedangkan masalah adalah suatu penyimpangan antara yang diharapkan dengan apa yang terjadi. Potensi dan masalah dalam penelitian ini didapatkan dengan cara melakukan observasi dan wawancara. Langkah selanjutnya yang harus dilakukan oleh peneliti adalah membuat rancangan desain dari produk yang akan dikembangkan. Desain produk media pembelajaran SPASI disesuaikan dengan materi dari Kompetensi Dasar yaitu tentang Menjelaskan organ pencernaan dan fungsinya pada hewan dan manusia serta cara memelihara kesehatan organ pencernaan manusia. Setelah membuat rancangan desain produk yang dikembangkan, peneliti melakukan validasi desain yang bertujuan untuk memberikan penilaian berdasarkan penilaian rasional tanpa melakukan uji coba di lapangan. Validasi desain dilakukan oleh validator yaitu ahli materi dan ahli media berupa angket. Setelah desain produk divalidasi oleh para ahli, maka peneliti melakukan revisi terhadap desain media pembelajaran SPASI berdasarkan masukan berupa kritik dan saran dari para ahli. Produk awal yang sudah direvisi dan divalidasi oleh ahli materi dan ahli media (draft II) kemudian diuji cobakan dalam skala terbatas. Uji coba ini dilakukan pada subjek lain diluar subjek penelitian sebanyak 6 siswa. Setelah melakukan revisi, tahap selanjutnya yang dilakukan adalah produk tersebut (draft III) diujicobakan dalam skala lebih luas dengan subyek penelitian sejumlah 40 siswa. Jenis data yang digunakan dalam penelitian ini adalah data kuantitatif. Hasil data yang diperoleh dari tanggapan siswa mengenai penggunaan media pada tahap uji coba pemakaian dan hasil kegiatan pretest dan posttest akan dianalisis menggunakan metode statistik inferensial.

Adapun indikator keberhasilan dalam penelitian yaitu, (1) Media pembelajaran SPASI dikatakan valid apabila persentase kriteria validitas media pembelajaran rata-rata $\geq 80 \%$ (Valid). (2) Media pembelajaran SPASI dikatakan praktis apabila persentase kriteria ketercapaian pembelajaran dan persentase tanggapan hasil tanggapan siswa rata-rata $\geq 80 \%$ (Sangat Baik). (3) Media pembelajaran SPASI dikatakan efektif dalam meningkatkan pemahaman konsep IPA apabila hasil belajar siswa setelah menggunakan media SPASI mengalami peningkatan pemahaman secara signifikan dibandingkan sebelum menggunakan media pembelajaran SPASI.

Caruban: Jurnal Ilmiah Pendidikan Dasar 3(1), 15-28, Januari 2020

DOI: http://dx.doi.org/10.33603/.v3i1.3037, p-ISSN 2615-1391, e-ISSN 2620-3219

(CProdi PGSD Universitas Swadaya Gunung Jati 


\section{Hasil dan Pembahasan}

Hasil dari penelitian ini berupa media pembelajaran SPASI materi pencernaan makanan hewan ruminansia.

\section{Tahapan Pengembangan Media Pembelajaran SPASI}

Pada tahap ini dilakukan observasi langsung di SDN Bendan Ngisor Semarang untuk mendapatkan potensi dan masalah yang ada. Berdasarkan hasil observasi dan wawancara dengan guru kelas V SDN Bendan Ngisor Semarang dapat diketahui bahwa sebagian besar siswa kesulitan dalam memahami materi pelajaran IPA terutama materi pencernaan makanan hewan ruminansia. Pengumpulan data/informasi sebagai bahan untuk mempersiapkan pengembangan media pembelajaran dengan melakukan observasi kegiatan pembelajaran dan fasilitas di SDN Bendan Ngisor Semarang. Pengumpulan data memperoleh hasil sebagai berikut.

Tabel 1. Hasil Data Observasi

\begin{tabular}{|c|c|c|}
\hline Indikator & Pernyataan & Keterangan \\
\hline \multirow{4}{*}{$\begin{array}{l}\text { Kegiatan } \\
\text { Pembelajaran }\end{array}$} & $\begin{array}{lr}\begin{array}{l}\text { Menggunakan } \\
\text { pembelajaran }\end{array} & \text { yang } \\
\text { inovatif } & \\
\end{array}$ & $\begin{array}{l}\text { Menggunakan metode ceramah } \\
\text { dalam pembelajaran }\end{array}$ \\
\hline & $\begin{array}{l}\text { Kedalaman materi } \\
\text { yang disampaikan } \\
\text { sesuai dengan tujuan } \\
\text { pembelajaran }\end{array}$ & $\begin{array}{l}\text { Kedalaman materi kurang sesuai } \\
\text { dengan tujuan pembelajaran. }\end{array}$ \\
\hline & $\begin{array}{l}\text { Media pembelajaran } \\
\text { yang digunakan sesuai } \\
\text { dengan materi }\end{array}$ & $\begin{array}{l}\text { Kurang sesuai dengana materi. } \\
\text { Materi proses pencernaan } \\
\text { makanan, tetapi yang digunakan } \\
\text { hanya media gambar. }\end{array}$ \\
\hline & $\begin{array}{l}\text { Media yang digunakan } \\
\text { menarik }\end{array}$ & $\begin{array}{l}\text { Kurang menarik karena gambar } \\
\text { terlalu kecil }\end{array}$ \\
\hline
\end{tabular}

Setelah tahap pengumpulan data selesai, maka tahap selanjutnya adalah desain produk. Setelah membuat rancangan desain produk yang dikembangkan, peneliti melakukan validasi desain yang bertujuan untuk memberikan penilaian berdasarkan penilaian rasional kepada ahli materi dan ahli media tanpa melakukan uji coba di lapangan.

Berikut merupakan saran dari ahli materi

Caruban: Jurnal Ilmiah Pendidikan Dasar 3(1), 15-28, Januari 2020

DOI: http://dx.doi.org/10.33603/.v3i1.3037, p-ISSN 2615-1391, e-ISSN 2620-3219

(CProdi PGSD Universitas Swadaya Gunung Jati 
a. Proses demonstrasi lidah belum begitu terlihat jelas.

b. Peran saliva tidak terlihat.

c. Pada bagian pencernaan diperut jala atau perut besar belum terlihat sempurna.

d. Perlu perbaikan dalam demonstrasi penyerapan nutris dari makanan hewan ruminansia dibagian usus.

Sedangkan oleh ahli media hanya mendapatkan sedikit saran karena menurut menurut ahli media ini sudah sangat bagus dan hanya perlu revisi sedikit, diantaranya adalah sebagai berikut.

a. Perbaikan pada bagian mulut sapi agar peran mengunyah terlihat lebih nyata.

b. Perbaikan pada bagian pencernaan hewan ruminansia (sapi) pada saat demonstrasi.

Pada uji coba produk skala terbatas data hasil tes siswa dalam penggunaan media pembelajaran SPASI melalui pretest dan posttest adalah sebagai berikut.

Tabel 2. Hasil Belajar Skala Terbatas

\begin{tabular}{llccc}
\hline No & Nama Siswa & L/P & Nilai Pretest & Nilai Posttest \\
\hline 1 & S-1 & L & 44 & 76 \\
\hline 2 & S-2 & P & 53 & 86 \\
\hline 3 & S-3 & L & 77 & 97 \\
\hline 4 & S-4 & $\mathrm{P}$ & 40 & 72 \\
\hline 5 & S-5 & $\mathrm{P}$ & 63 & 92 \\
\hline 6 & S-6 & $\mathrm{L}$ & 57 & 84 \\
\hline Nilai Terendah & & 40 & 72 \\
\hline Nilai Tertinggi & & 77 & 97 \\
\hline Nilai rata-rata & & 55.6 & 84.5 \\
\hline
\end{tabular}

Tahap uji coba produk ini juga dilakukan dengan melihat tanggapan siswa. Berikut data hasil angket yang diberikan kepada 6 siswa yang telah melakukan uji coba produk. Persentase kepraktisan dari hasil uji coba produk skala terbatas sebesar $96,67 \%$. 
Setelah dilakukan uji coba kelompok kecil dan tidak ditemukan adanya kelemahan media atau hambatan, maka peneliti melanjutkan pada tahap selanjutnya yaitu uji coba pemakaian skala luas. Dilakukan pada seluruh subjek penelitian yaitu kelas V SDN Bendan Ngisor Semarang yang berjumlah 40 siswa. Persentase pada tanggapan siswa memperoleh skor $95,3 \%$. Berikut adalah hasil tanggapan siswa pada uji coba pemakaian skala luas.

Tabel 3. Hasil Belajar Skala Luas

\begin{tabular}{|c|c|c|c|}
\hline \multirow{2}{*}{ Pertanyaan } & \multicolumn{2}{|c|}{ Respon } & \multirow{2}{*}{ Total } \\
\hline & $\mathrm{Ya}$ & Tidak & \\
\hline $\begin{array}{l}\text { Apakah media SPASI yang ditampilkan } \\
\text { dalam proses pembelajaran menarik? }\end{array}$ & 37 & 3 & 40 \\
\hline $\begin{array}{l}\text { Apakah media SPASI yang ditampilkan } \\
\text { dalam proses pembelajaran membantu } \\
\text { dalam belajar? }\end{array}$ & 40 & 0 & 40 \\
\hline $\begin{array}{l}\text { Apakah media SPASI yang ditampilkan } \\
\text { dalam proses pembelajaran terlihat } \\
\text { jelas? }\end{array}$ & 35 & 5 & 40 \\
\hline $\begin{array}{l}\text { Apakah materi pencernaan makanan } \\
\text { hewan ruminansia dalam media SPASI } \\
\text { mudah dipahami? }\end{array}$ & 38 & 2 & 40 \\
\hline $\begin{array}{l}\text { Apakah media SPASI } \\
\text { pencernaan materi } \\
\text { ruminansia bermanfaat } \\
\text { pembelajaran IPA? }\end{array}$ & 39 & 1 & 40 \\
\hline $\begin{array}{l}\text { Apakah media SPASI ini dapat } \\
\text { memotivasi kamu untuk belajar? }\end{array}$ & 38 & 2 & 40 \\
\hline $\begin{array}{l}\text { Apakah kamu senang belajar dengan } \\
\text { menggunakan media pebelajaran } \\
\text { SPASI? }\end{array}$ & 39 & 1 & 40 \\
\hline $\begin{array}{l}\text { Apakah kamu senang belajar dengan } \\
\text { menggunakan media pembelajaran } \\
\text { SPASI }\end{array}$ & 39 & 1 & 40 \\
\hline Jumlah & 305 & 15 & 320 \\
\hline
\end{tabular}

Berdasarkan data tersebut diperoleh persentase kepraktisan dari hasil tanggapan siswa sebesar 95,3\%. Berdasarkan data hasil analisis tersebut menunjukkan bahwa media pembelajaran SPASI materi pencernaan makanan hewan ruminansia termasuk kategori sangat baik.

Caruban: Jurnal Ilmiah Pendidikan Dasar 3(1), 15-28, Januari 2020

DOI: http://dx.doi.org/10.33603/.v3i1.3037, p-ISSN 2615-1391, e-ISSN 2620-3219

CProdi PGSD Universitas Swadaya Gunung Jati 
2. Hasil Kelayakan Media Pembelajaran SPASI yang Valid, Praktis, dan Efektif.

Menurut Niveen dalam Subekti (2010: 76), kevalidan suatu produk dikaitkan dengan dua hal, yaitu apakah hasil dari pengembangan didasarkan pada rasional teoritis yang kuat dan apakah terdapat konsistensi secara internal. Untuk mengetahui kevalidan media pembelajaran SPASI, maka peneliti melakukan tahapan validasi kepada para ahli dengan melihat aspek media dan materi. Berdasarkan validasi ahli media dan ahli materi dapat diperoleh hasil mengenai media pembelajaran SPASI pada materi pencernaan makanan hewan ruminansia. Berikut adalah hasil uji validasi ahli materi dan ahli media pembelajaran SPASI.

Tabel 4 Hasil Kevalidan dari Para Ahli

\begin{tabular}{clrcc}
\hline Aspek & \multicolumn{1}{c}{ Dosen Ahli } & Hasil & Presentase & Keterangan \\
\hline Media & Rofian, S.Pd., M.Pd. & 64 & $97,23 \%$ & Sangat Valid \\
\hline Materi & Ferine, M.Pd. & 57 & $89,23 \%$ & Sangat Valid \\
\hline
\end{tabular}

Berdasarkan hasil persentase validitas pada Tabel 4, yaitu 97,23\% untuk ahli media menunjukkan bahwa hasil media pembelajaran SPASI termasuk kategori "sangat valid" dan 89,23\% untuk ahli materi menunjukkan materi dalam media pembelajaran SPASI termasuk kategori "sangat valid".

Menurut Nieveen dalam Subekti (2010:77), kepraktisan dapat dilihat dari dua hal, yaitu jika ahli dan praktisi menyatakan bahwa sesuatu yang dikembangkan dapat terapkan dan dalam kenyataannya sesuatu yang dikembangkan itu memang benar-benar dapat diterapkan. Untuk mengetahui kepraktisan dalam penggunaan media pembelajaran SPASI pada materi pencernaan makanan hewan ruminansia dapat diperoleh dengan dua cara yaitu observasi pelaksanaan pembelajaran dan angket siswa. Berikut data hasil observasi pelaksanaan pembelajaran dan angket siswa pada uji coba pemakaian skala luas yang dapat dilihat pada Tabel 5.

Caruban: Jurnal Ilmiah Pendidikan Dasar 3(1), 15-28, Januari 2020

DOI: http://dx.doi.org/10.33603/.v3i1.3037, p-ISSN 2615-1391, e-ISSN 2620-3219

(CProdi PGSD Universitas Swadaya Gunung Jati 
Tabel 5. Hasil Penilaian Observasi dan Angket siswa

\begin{tabular}{cccc}
\hline & \multicolumn{2}{c}{$\begin{array}{c}\text { Observasi Pelaksanaan } \\
\text { Pembelajaran }\end{array}$} & \multirow{2}{*}{ Angket Siswa } \\
\cline { 2 - 3 } & O1 & O2 & \\
\hline Skor Total & 89 & 86 & 233 \\
\hline Presentase & $89 \%$ & $86 \%$ & $93,20 \%$ \\
\hline Kriteria & Sangat Baik & Sangat Baik & Sangat Baik \\
\hline Rata-rata & \multicolumn{3}{c}{$89.4 \%$} \\
Kepraktisan & \multicolumn{3}{c}{ Sangat Baik } \\
\hline Kriteria & \multicolumn{3}{c}{}
\end{tabular}

Kriteria ketiga dalam media pembelajaran SPASI yaitu efektif. Menurut Arsyad (2013: 217), efektifitas dapat dilihat dari dua aspek, yaitu bukti-bukti empiris mengenai hasil belajar siswa yang dihasilkan oleh sistem intruksional, dan bukti-bukti yang menunjukkan berapa banyak kontribusi media atau media program terhadap keberhasilan dan keefektifan proses instruksional. Media pembelajaran SPASI materi pencernaan makanan hewan ruminansia dikatakan efektif apabila tes hasil belajar siswa mengalami peningkatan secara signifikan setelah menggunakan media pembelajaran SPASI. Tes hasil belajar siswa berupa tes kognitif sebanyak 20 soal pilihan ganda dan 50 soal uraian yang diberikan kepada setiap siswa sebagai pretest dan posttest. Tes ini diberikan dalam uji coba produk (skala terbatas) dan uji coba pemakaian (Skala luas). Uji coba produk terdiri dari 6 siswa yang diambil secara acak, dan uji coba pemakaian seluruh siswa kelas V SDN Bendan Ngisor Semarang. Pada uji coba produk skala terbatas, dapat diketahui bahwa nilai rata-rata hasil belajar peserta didik pada uji coba produk skala terbatas untuk nilai pretest peserta didik sebesar 55,6 sedangkan rata-rata posttest peserta didik sebesar 84,5 dan rata-rata nilai tersebut telah mencapai KKM (Kriteria Ketuntasan Minimal) mata pelajaran IPA yang berlaku yakni 80. Setelah dilakukan uji coba produk (skala terbatas) dan tidak ditemukan adanya kelemahan media atau hambatan, maka peneliti melanjutkan tahap selanjutnya yaitu uji coba pemakaian (Skala luas). Pada uji coba pemakaian skala luas, dapat diketahui bahwa nilai ratarata hasil belajar peserta didik pada uji coba pemakaian skala luas untuk nilai pretest sebesar 59,92 sedangkan rata-rata posttest peserta didik sebesar 83,8 dan rata-rata nilai tersebut telah mencapai KKM (Kriteria Ketuntasan

Caruban: Jurnal Ilmiah Pendidikan Dasar 3(1), 15-28, Januari 2020

DOI: http://dx.doi.org/10.33603/.v3i1.3037, p-ISSN 2615-1391, e-ISSN 2620-3219

CProdi PGSD Universitas Swadaya Gunung Jati 
Minimal) mata pelajaran IPA yang berlaku yakni 80. Dengan demikian dapat diketahui bahwa media pembelajaran SPASI dikatakan telah memenuhi kelayakan dari segi efektivitas dalam proses pembelajaran karena dengan menggunakan media pembelajaran SPASI dalam proses pembelajaran dapat meningkatkan pemahaman peserta didik secara mendalam mengenai materi, mempermudah mengingat materi jangka panjang, dan menemukan fakta-fakta mengenai materi yang abstrak terhadap materi perncernaan makanan pada hewan ruminansia sehingga hasil belajar pun meningkat secara signifikan. Hal ini sesuai dengan pendapat Sones (dalam McCloud, 2008:106), bahwa pengaruh menggunakan media pembelajaran SPASI dapat meningkatkan kualitas pembelajaran yang dilihat dalam hasil tes belajar siswa. Begitu pula menurut Sadiman (2008:182) bahwa tes formatif dimaksudkan untuk mengumpulkan data tentang efektifitas dan efisiensi bahan-bahan pembelajaran. Keefektifan pelaksanaan proses pembelajaran dengan media diukur melalui bukti-bukti hasil belajar siswa yang dihasilkan dalam sistem pembelajaran (Arsyad dalam Musfiqon, 2012:150).

\section{Simpulan dan Rekomendasi}

Berdasarkan dari hasil penelitian dan pembahasan maka dapat disimpulkan bahwa produk yang dihasilkan adalah produk yang layak digunakan untuk penelitian dan proses pembelajaran. Kelayakan produk ditentukan dari tiga kriteria, yaitu valid, praktis, dan efektif. Kevalidan media pembelajaran SPASI materi pencernaan makanan hewan ruminansia ditentukan dari hasil penilaian yang diberikan oleh ahli media dan ahli materi. Pada ahli media, kevalidan media sebesar 91,4\% dan pada ahli materi kevalidan media pembelajaran SPASI sebesar $87,6 \%$ dalam kategori "Sangat Valid". Kepraktisan media pembelajaran SPASI materi sistem pencernaan makanan pada hewan ruminansia ditentukan dari hasil observasi pelaksanaan pembelajaran dan angket siswa. Kepraktisan penggunaan media pembelajaran SPASI untuk obsever pertama sebesar $89 \%$ dan obsever kedua sebesar $86 \%$. Dan pada angket siswa, kepraktisan penggunaan media pembelajaran berbasis flash untuk "ya" sebesar 305 dan untuk "tidak" sebesar 15 Sehingga rata-rata perolehan hasil keseluruhan 95,3\%. Dengan demikian rata-rata perolehan hasil keseluruhan mengenai kepraktisan penggunaan media SPASI dan angket siswa sebesar 89,4\% dalam tingkat

Caruban: Jurnal Ilmiah Pendidikan Dasar 3(1), 15-28, Januari 2020

DOI: http://dx.doi.org/10.33603/.v3i1.3037, p-ISSN 2615-1391, e-ISSN 2620-3219

CProdi PGSD Universitas Swadaya Gunung Jati 
kategori "Sangat Baik" dalam proses pembelajaran. Keefektifan media pembelajaran SPASI materi pencernaan makanan hewan ruminansia ditentukan dari hasil penilaian tes belajar siswa dari segi kognitif setelah menggunakan media pembelajaran SPASI. Nilai rata-rata hasil belajar siswa pada uji coba produk skala terbatas untuk nilai pretest siswa sebesar 55,6 sedangkan rata-rata posttest siswa sebesar 84,5 dan rata-rata nilai tersebut telah mencapai KKM (Kriteria Ketuntasan Minimal) mata pelajaran IPA yang berlaku yakni 80 . Peningkatan hasil belajar siswa ini dapat dilihat sedangkan pada uji coba pemakaian skala luas untuk nilai pretest sebesar 59,92 sedangkan rata-rata posttest siswa sebesar 83,8.

Adapun rekomendasi yang dapat penulis berikan bagi para peneliti terutama dalam penelitian dan pengembangan produk media, yakni bahwa dalam pengembangan media pembelajaran haruslah dapat menentukan materi yang tepat dan menarik untuk disajikan dalam media pembelajaran dan menjadi acuan penelitian bila ingin menerapkan dengan materi yang berbeda. Kemudian penggunaan bahan harus aman dalam penggunaan dalam menunjang proses pembelajaran di kelas.

\section{Daftar Pustaka}

Astuti, Dwi. 2008. Teknik Membuat Animasi Profesional Menggunakan Macromedia Flash. Yogyakarta: Andi

Arsyad, Azhar. 2013. Media Pembelajaran. Jakarta: PT Raja Grafindo Persada Indriana, Dina 2011. Ragam Alat Bantu Media Pengajaran. Yogyakarta: Diva Press

Ihzandy, Edo. 2016. Pengembangan Multimedia Sistem Tata Surya Berbasis Flash Pada Mata Pelajaran Ilmu Pengetahuan Alam Kelas VI SDN 2 Tanggulanom, Selopampang, Temanggung Jawa Tengah. Vol V Nomor 2. (Online), http://journal.student.uny.ac.id [diakses tanggal 24 Desember 2019]

Komsiyah, Indah. 2012. Belajar dan Pembelajaran. Yogyakarta: Teras

Kustandi, Cecep. Bambang Sutjipto. 2011. Media Pembelajaran Manual dan

Digital. Bogor: Ghalia Indonesia

Maryani, Ika. 2015. Pendekatan Scientific dalam Pembelajaran di Sekolah Dasar (Teori dan Praktek). Yogykarta: CV. Budi Utama

Roesminingsih, MV dan Hadi Susarno. 2013. Teori dan Praktik Pendidikan. Surabaya: Unesa University Press.

Caruban: Jurnal Ilmiah Pendidikan Dasar 3(1), 15-28, Januari 2020

DOI: http://dx.doi.org/10.33603/.v3i1.3037, p-ISSN 2615-1391, e-ISSN 2620-3219

(CProdi PGSD Universitas Swadaya Gunung Jati 
Rullyanda, Dodi. Hakikat dan Tujuan Pembelajaran IPA di SD. http://dodirullyandapgsd.blogspot.co.id/2014/08/hakikat-dan-tujuanpembelajaran-ipa.html?m=1\# (diakses 20 Desember 2019).

Sudjana, Nana. 2011. Penilaian Hasil Proses Belajar Mengajar. Bandung: PT Indeks

Sugiyono. 2014. Metode Penelitian Kuantitatif Kualitatif Dan RED. Bandung: Alfabeta

Susilana, dan Riyana. 2007. Media Pembelajaran. Bandung: CV. wacana Prima

Okur, Ibrahim. 2010. The effect of Using Animations on Pre-service Science Teachers' Science Achievment. (online). http://sciencedirect.com/science.article/pii/202229X [diakses tanggal 18 Desember 2019] 